\title{
Characterization of multiple antilisterial peptides produced by sakacin P-producing Lactobacillus sakei subsp. sakei $2 \mathrm{a}$
}

\author{
Kátia G. Carvalho' ${ }^{2}$ - Felipe H. S. Bambirra ${ }^{3}$ Jacques R. Nicoli ${ }^{3}$. Jamil S. Oliveira ${ }^{4}$. Alexandre M. C. Santos ${ }^{4,6}$. \\ Marcelo P. Bemquerer ${ }^{5}$. Antonio Miranda ${ }^{7}$. Bernadette D. G. M. Franco ${ }^{1}$
}

Received: 31 August 2017 / Revised: 21 December 2017 / Accepted: 4 January 2018 / Published online: 18 January 2018

๑) Springer-Verlag GmbH Germany, part of Springer Nature 2018

\begin{abstract}
Antimicrobial compounds produced by lactic acid bacteria can be explored as natural food biopreservatives. In a previous report, the main antimicrobial compounds produced by the Brazilian meat isolate Lactobacillus sakei subsp. sakei 2a, i.e., bacteriocin sakacin P and two ribosomal peptides (P2 and P3) active against Listeria monocytogenes, were described. In this study, we report the spectrum of activity, molecular mass, structural identity and mechanism of action of additional six antilisterial peptides produced by $L$ b. sakei $2 \mathrm{a}$, detected in a $24 \mathrm{~h}$-culture in MRS broth submitted to acid treatment ( $\mathrm{pH}$ 1.5 ) and proper fractionation and purification steps for obtention of free and cell-bound proteins. The six peptides presented similarity to different ribosomal proteins of $L b$. sakei subsp sakei $23 \mathrm{~K}$ and the molecular masses varied from 4.6 to $11.0 \mathrm{kDa}$. All peptides were capable to increase the efflux of ATP and decrease the membrane potential in Listeria monocytogenes. The activity of a pool of the obtained antilisterial compounds [enriched active fraction (EAF)] against Listeria monocytogenes in a food model (meat gravy) during refrigerated storage $\left(4{ }^{\circ} \mathrm{C}\right)$ for 10 days was also tested and results indicated that the populations of L. monocytogenes in the food model containing the acid extract remained lower than those at time 0 -day, evidencing that the acid extract of a culture of $L b$. sakei $2 \mathrm{a}$ is a good technological alternative for the control of growth of L. monocytogenes in foods.
\end{abstract}

Keywords Lactobacillus sakei subsp. sakei 2a $\cdot$ Listeria monocytogenes $\cdot$ Multiple antimicrobial peptides $\cdot$ Meat gravy Biopreservation

Communicated by Erko Stackebrandt.

Chemical compounds studied in this article: sodium chloride (PubChem CID: 5234), phosphoric acid (PubChem CID: 1004), trifluoroacetic acid (PubChem CID: 45039676), acetonitrile (PubChem CID: 6342), hepes potassium Salt (PubChem CID: 23702134), glucose (PubChem CID: 82400), nisin (PubChem CID: 16130280), valinomycin (PubChem CID: 5649), potassium chloride (PubChem CID: 4873).

Kátia G. Carvalho

ka20_04@hotmail.com

1 Food Research Center, Departamento de Alimentos e Nutrição Experimental, Faculdade de Ciências Farmacêuticas, Universidade de São Paulo, São Paulo, SP, Brazil

2 Planta Piloto de Procesos Industriales Microbiológicos (PROIMI), CONICET, Av. Belgrano y Pje. Caseros, San Miguel de Tucumán 4000, Tucumán, Argentina

3 Departamento de Microbiologia, Instituto de Ciências Biológicas, Universidade Federal de Minas Gerais, Belo Horizonte, MG, Brazil

\section{Introduction}

Lactobacillus sakei subsp. sakei 2a is a lactic acid bacteria isolated from a Brazilian pork product, capable to inhibit the growth of Listeria monocytogenes in vitro and in meat products by the production of bacteriocin(s) (De Martinis

4 Departamento de Bioquímica e Imunologia, Instituto de Ciências Biológicas, Universidade Federal de Minas Gerais, Belo Horizonte, MG, Brazil

5 EMBRAPA Recursos Genéticos e Biotecnologia, Parque Estação Biológica, Brasília, DF, Brazil

6 Departamento de Ciências Fisiológicas, Universidade Federal do Espírito Santo, Vitória, ES, Brazil

7 Departamento de Biofísica, Universidade Federal de São Paulo, São Paulo, SP, Brazil 
and Franco 1998). The mechanism of action of the bacteriocin produced by this strain was described in the early 2000s (Rosa et al. 2002) and a study conducted afterwards has shown that the main bacteriocin produced by this strain is sakacin $\mathrm{P}$ (peptide $\mathrm{P} 1$ ), along with two additional antilisterial peptides (P2 and P3) (Carvalho et al. 2010). Cationexchange and reversed-phase chromatographic purification, followed by mass spectrometry and determination of amino acid sequences, indicated that $\mathrm{P} 2$ and $\mathrm{P} 3$ are identical to the $30 \mathrm{~S}$ ribosomal protein $\mathrm{S} 21$ and to a histone-like DNA-binding protein HV of Lb. sakei subsp sakei $23 \mathrm{~K}$, respectively. Sakacin P and the peptides P2 and P3 were capable of affecting the membrane electrochemical potential of L. monocytogenes. Genes sak, lis and his in the DNA of Lb. sakei 2a, involved in the production of sakacin $\mathrm{P}$ and peptides $\mathrm{P} 2$ and $\mathrm{P} 3$, respectively, were cloned in $\mathrm{pET} 28 \mathrm{~B}$ expression vector and the resulting plasmids were transformed in Escherichia coli KRX competent cells. The resulting transformants effectively inhibited several L. monocytogenes strains (Carvalho et al. 2010).

Control of L. monocytogenes in foods and the food processing environment is of great relevance due to the occurrence of numerous food-borne listeriosis cases and outbreaks, affecting pregnant women, the sick and elderly, neonates, infants and immuno-compromised patients. Control of growth of L. monocytogenes in foods and the food industry environment is challenging because L. monocytogenes presents high physiological resistance to acidic $\mathrm{pH}$, low temperature and high salt concentration, and capability to form persistent biofilms on the surfaces of equipment and utensils in food processing plants. L. monocytogenes can be particularly threatening in ready-to-eat foods, where there is no kill step to eliminate or reduce the pathogen before consumption (Buchanan et al. 2017).

Some studies have reported that some lactic acid bacteria strains are capable of production of multiple bacteriocins. Sawa et al. (2013) have shown that Lactobacillus sakei D98, isolated from rice malt, produced at least three class IIa-like or class IId bacteriocins (sakacins D98a, D98b and D98c), with different mode of action and differences in the amino acids sequences and position of the disulfite bridge compared to other class IIa bacteriocins. Also, Ustyugova et al. (2012) reported that Lactococcus lactis subsp lactis 194-K, isolated from cow milk in Buryatia, Russia, produces nisin A and another polypeptide (194-D) capable to suppress growth of Gram-positive and Gram-negative bacteria. Lactococcus lactis LMG2081, isolated from the European pear, produces two bacteriocins: the lantibiotic lacticin LMG (class I bacteriocin) and lactococcin G (Class IIb bacteriocin) (Mirkovic et al. 2016). Another raw milk isolate (Enterococcus faecium GGN7) obtained in Tunisia produced both enterocins A and B, plus a 3215.5 peptide active against Gram-negative bacteria (Gaaloul et al. 2014). Weissella helenica QU13, isolated from pickles, produces weissellicins $\mathrm{Y}$ and $\mathrm{M}$, depending on the nutrition conditions (Masuda et al. 2015). The Brazilian meat isolate $L b$. sakei 2a produces sakacin $\mathrm{P}$ and several antilisterial compounds, two of them (peptides P2 and P3) described in Carvalho et al. (2010). In this study, we report the properties (spectrum of activity, molecular mass, structural identity and mechanism of action) of other six antilisterial compounds produced by this strain, obtained after submitting a 24-h culture in MRS broth to proper purification steps for obtention of free and cell-bound peptides. The activity of these antilisterial compounds against Listeria monocytogenes in a food model (meat gravy) during refrigerated storage $\left(4^{\circ} \mathrm{C}\right)$ for 10 days was also tested.

\section{Material and methods}

\section{Bacterial cultures and media}

The bacteriocinogenic strain used in the study was $L$. sakei subsp. sakei 2a, isolated from Brazilian porcine sausage (De Martinis and Franco 1998). The target strains used in the study are listed in Table 1. Lactobacillus sp., Bifidobacterium bifidum Bb12, Enterococcus sp., Lactococcus lactis and $L b$. sakei 2 a were grown in MRS broth (Difco, Detroit, MI, USA) at $25^{\circ} \mathrm{C}$ for $18 \mathrm{~h}$, and the other bacteria were grown in BHI (Difco) at $37^{\circ} \mathrm{C}$ for $24 \mathrm{~h}$. Antimicrobial activity of $L b$. sakei 2 a was confirmed by the double-layer diffusion test, according to Farias et al. (1994), using Listeria monocytogenes Scott A as indicator. Results were expressed as Arbitrary Units per milliliter $\left(\mathrm{AU} \cdot \mathrm{mL}^{-1}\right)$, which corresponded to the highest dilution that resulted in an inhibition halo against L. monocytogenes. Nisin (1000 UI. $\mathrm{mL}^{-1}$, Nisaplin, Danisco, Denmark) and distilled water were used as positive and negative controls, respectively.

\section{Obtention of the free and cell-bound antimicrobial compounds produced by $L b$. sakei $2 \mathrm{a}$}

Eight liters of a culture of $L b$. sakei $2 \mathrm{a}$, in MRS broth incubated at $25{ }^{\circ} \mathrm{C}$ to reach the early stationary phase (c.a. $5 \times 10^{8} \mathrm{CFU} \cdot \mathrm{mL}^{-1}$ ), were submitted to $\mathrm{pH}$ adjustment at 6.0 and heated at $70{ }^{\circ} \mathrm{C}$ for $30 \mathrm{~min}$. Cells were harvested by centrifugation at $10,000 \mathrm{~g}$ for $15 \mathrm{~min}$ and the supernatant assayed for bacteriocin activity (free antimicrobials).

For extraction of the antimicrobial compounds bound to the $L b$. sakei 2 a cells, the resulting pellet was washed with $5 \mathrm{mmol} \cdot \mathrm{L}^{-1} 2$-( $N$-morpholin)-ethanesulphonate (MES) buffer, $\mathrm{pH} 6.5$, and suspended in $400 \mathrm{~mL}$ of $100 \mathrm{mmol} \cdot \mathrm{L}^{-1}$ $\mathrm{NaCl}, \mathrm{pH} 1.5$, adjusted with an aqueous solution of $5 \%$ phosphoric acid. The suspension was homogenized for $1 \mathrm{~h}$ at $4{ }^{\circ} \mathrm{C}$ by magnetic stirring and centrifuged at 10,000 $\mathrm{g}$ for $20 \mathrm{~min}$ (Yang et al. 1992). The $\mathrm{pH}$ of the acid extract was adjusted to 
Table 1 Antimicrobial activity $\left(\mathrm{AU} \cdot \mathrm{mL}^{-1}\right)$ of the six antimicrobial compounds $\left(1000 \mathrm{nmol} \cdot \mathrm{L}^{-1}\right)$ produced by Lactobacillus sakei subsp. sakei 2a

\begin{tabular}{|c|c|c|c|c|c|c|}
\hline \multirow[t]{2}{*}{ Target strain } & \multicolumn{6}{|c|}{ Antimicrobial compounds } \\
\hline & $\mathrm{P} 4$ & P5 & P6 & P7 & P8 & P9 \\
\hline Bacillus cereus ATCC 11778 & $-{ }^{\mathrm{a}}$ & - & - & - & - & - \\
\hline Bacteroides sp. ATCC 49056 & - & - & - & - & - & - \\
\hline Bifidobacterium bifidum BB 12 & - & - & - & - & - & - \\
\hline Enterobacter aerogenes ATCC 13048 & - & - & - & - & - & - \\
\hline Enterococcus canis 33 & 120 & 90 & - & - & 100 & - \\
\hline Enterococcus faecalis ATCC 19483 & 120 & 90 & 140 & 120 & 100 & 140 \\
\hline Enterococcus faecium 988 & 120 & 90 & - & - & - & - \\
\hline Enterococcus hirae 28 & 120 & 90 & - & 120 & - & - \\
\hline Escherichia coli ATCC 8739 & - & - & - & - & - & - \\
\hline Escherichia coli O157:H7 ATCC 35150 & - & - & - & - & - & - \\
\hline Lactobacillus acidophilus LA 5 & - & - & - & - & - & - \\
\hline Lactobacillus acidophilus LAC 4 & - & - & - & - & - & - \\
\hline Lactobacillus casei BL 20 & - & - & - & - & - & - \\
\hline Lactobacillus helveticus 1176 & - & - & - & - & - & - \\
\hline Lactobacillus sakei ATCC 15521 & 120 & 90 & 140 & 120 & 100 & 140 \\
\hline Lactobacillus paracasei LBC 82 & - & - & - & - & - & - \\
\hline Lactococcus lactis subsp. lactis 9 & - & - & - & - & - & - \\
\hline Listeria innocua Li7 & 120 & 90 & 140 & 120 & 100 & 140 \\
\hline Listeria monocytogenes ATCC 7644 & 120 & 90 & 140 & 120 & 100 & 140 \\
\hline Listeria monocytogenes Scott A & 120 & 90 & 140 & 120 & 100 & 140 \\
\hline Listeria seeligeri ATCC 35967 & 120 & 90 & 140 & 120 & 100 & 140 \\
\hline Salmonella enteriditis ATCC 13076 & - & - & - & - & - & - \\
\hline Salmonella typhimurium ATCC 14028 & - & - & - & - & - & - \\
\hline Staphylococcus aureus ATCC 6541 & - & - & - & - & - & - \\
\hline Staphylococcus aureus ATCC 29213 & - & - & - & - & - & - \\
\hline Staphylococcus epidermidis ATCC 12228 & 120 & 90 & 140 & 120 & 100 & - \\
\hline Shigella sonnei ATCC 25931 & - & - & - & - & - & - \\
\hline Pseudomonas aeruginosa 25723 & - & - & - & - & - & - \\
\hline Pseudomonas mirabilis ATCC 22906 & - & - & - & - & - & - \\
\hline
\end{tabular}

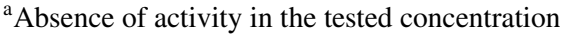

6.0 (neutralized acid extract), and assayed for antimicrobial activity using the double-layer diffusion test, according to Farias et al. (1994), using Listeria monocytogenes Scott A as indicator. The neutralized acid extract was concentrated ten times by ultra-filtration in an Amicon System (Millipore-Merck, Billerica, MA, USA) with 1000 Da molecularweight-cut-off membrane and then freeze-dried. The protein concentration in the neutralized acid extract was determined by the Bradford method (Bradford 1976).

\section{Characterization of the antimicrobial compounds}

The procedures for purification of the antimicrobial compounds, the protein sequencing and determination of molecular mass by mass spectrometry were the same previously published (Carvalho et al. 2010). The influence of the proteases trypsin, proteinase $\mathrm{K}$ and pronase on antilisterial activity of each purified fraction containing the antimicrobial was tested as described in Carvalho et al. 2010.

The mechanism of action of each purified fraction containing the antimicrobial was determined by means of two measurements: (1) proton motive force depletion, according to Carvalho et al. (2010) and (2) efflux of ATP, according to Guihard et al. (1993). The detection of efflux of ATP was based in a bioluminescence assay, where L. monocytogenes Scott A cells were cultivated in $25 \mathrm{~mL}$ of $\mathrm{BHI}$ broth at $30{ }^{\circ} \mathrm{C}$ until absorbance reached values in the range from 0.6 to 1.0 at $600 \mathrm{~nm}$ (corresponding to $2 \times 10^{9}$ cells). Bacterial cells were centrifuged at $3000 \mathrm{~g}$ for $10 \mathrm{~min}$, washed twice with $50 \mathrm{mmol} \cdot \mathrm{L}^{-1} \mathrm{MES}$ buffer, $\mathrm{pH}$ 6.5, and suspended in $2.5 \mathrm{~mL}$ of a $10 \mathrm{mmol} \cdot \mathrm{L}^{-1} \mathrm{KCl}$ solution containing $1 \%$ $\left(\mathrm{w} \cdot \mathrm{v}^{-1}\right)$ D-glucose. For total ATP measurement, $20 \mu \mathrm{L}$ of L. monocytogenes Scott A suspension was added to $80 \mu \mathrm{L}$ of dimethyl sulfoxide and the suspension was diluted with $4.9 \mathrm{~mL}$ of distilled water. For measurement of extracellular 
ATP, $20 \mu \mathrm{L}$ of L. monocytogenes Scott A suspension was added to $50 \mathrm{mmol} \cdot \mathrm{L}^{-1} \mathrm{MES}$ buffer, $\mathrm{pH} 6.5$, and $100 \mu \mathrm{L}$ of this suspension was mixed with $100 \mu \mathrm{L}$ of the ATP solution (Life Technologies) and different concentrations of the purified protein or nisin (positive control) $(0.1,0.25,0.5$, and $1.0 \mu \mathrm{mol} \cdot \mathrm{L}^{-1}$ ). The MES buffer and ATP solution (without the antibacterial proteins or nisin) was used as negative control. Bioluminescence was measured after 15, 17, 27 and $37 \mathrm{~min}$ and expressed as nmol per milligram of dry weight cells (nmol. $\mathrm{mg}^{-1}$ ), based on a standard curve built correlating bioluminescence intensity with ATP concentration. The standard curve was obtained using the standard ATP of the ATP assay kit (Life Technologies).

\section{Test for activity against listeria monocytogenes in a food model (meat gravy)}

A simulated meat gravy was prepared mixing proteose peptone $\left(1.8 \% \mathrm{w} \cdot \mathrm{v}^{-1}\right)$, meat extract $\left(1.2 \% \mathrm{w} \cdot \mathrm{v}^{-1}\right)$, yeast extract $\left(0.6 \% \mathrm{w} \cdot \mathrm{v}^{-1}\right)$ and corn starch $\left(2.0 \% \mathrm{w} \cdot \mathrm{v}^{-1}\right)$ (Alves et al. 2003). Peptone, meat and yeast extracts were from Oxoid Ltd-Thermo Scientific, Hampshire, Basingstoke, UK-and starch was from Corn Products Brazil, Sao Paulo, SP, Brazil. The gravy was sterilized by autoclaving at $121{ }^{\circ} \mathrm{C}$ for $20 \mathrm{~min}$. Six liters of MRS were inoculated with $L$ b. sakei $2 \mathrm{a}$ and used to prepare the neutralized acid extract, following the procedure described in 2.2. This extract was submitted to reversed-phase chromatography and the fraction eluted at 10-17 min retention time, corresponding to the most active fraction (EAF-enriched active fraction), was used in the test. The meat gravy was divided into five $50 \mathrm{~mL}$ portions (A-E) and L. monocytogenes Scott A $\left(10^{3} \mathrm{CFU} \cdot \mathrm{mL}^{-1}\right)$ and the following additives/cultures: A-none (control); $\mathrm{B}-$ culture of Lb. sakei $2 \mathrm{a}-10^{6} \mathrm{CFU} \cdot \mathrm{mL}^{-1}$; C-EAF: $0.1 \%$ $\mathrm{w} \cdot \mathrm{v}^{-1}$; D-EAF: $0.2 \% \mathrm{w} \cdot \mathrm{v}^{-1}$; E nisin: $0.1 \% \mathrm{w} \cdot \mathrm{v}^{-1}$ were added. The inoculated gravy portions were maintained at $4{ }^{\circ} \mathrm{C}$ for 10 days, and counts of L. monocytogenes Scott A and $L b$. sakei 2 a were performed at times 0,5 and 10 days. For counting, gravy portions were submitted to serial decimal dilutions in $0.85 \% \mathrm{NaCl}\left(\mathrm{w} \cdot \mathrm{v}^{-1}\right)$ solution and $100 \mu \mathrm{L}$ of each dilution were spread plated onto two plates of Oxford agar (Oxoid) for the enumeration of L. monocytogenes Scott A and two plates of MRS agar (Oxoid) agar for enumeration of Lb. sakei 2a. Plates were incubated at $37^{\circ} \mathrm{C}$ for $48 \mathrm{~h}$, colonies were counted and results expressed as $\log \mathrm{CFU} \cdot \mathrm{mL}^{-1}$. All experiments were done three times.

\section{Statistical analysis}

Variance analysis (ANOVA) was applied to results of microbial counts in the simulated meat gravy. Data were expressed as means \pm standard error. The growth of L. monocytogenes Scott A during storage of meat gravy was evaluated using regression analyses. Statistical analysis was performed using the Fast Statistic software (Fatesoft Version 2.0 Demo, 2014). Results with $p<0.05$ were considered significant.

\section{Results and discussion}

The treatment of the culture of Lb. sakei $2 \mathrm{a}$ in MRS with an acidified solution ( $\mathrm{pH} 1.5)$ and extraction of the antimicrobial compounds bound to the cell walls combined with reversed-phase chromatography purification, followed by mass spectrometry and Edman degradation for identification, resulted in the detection of six new antilisterial compounds produced by the strain ( $\mathrm{P} 4-\mathrm{P} 9)$, in addition to sakacin $\mathrm{P}$ and peptides $\mathrm{P} 2$ and $\mathrm{P} 3$ previously described (Carvalho et al. 2010). The six antimicrobial compounds were consistently present in the cell-free supernatants in separate experiments. All compounds were sensitive to the tested proteolytic enzymes, indicating their proteinaceous nature. The peptides P4 to P9 were heat stable, maintaining the biological activity after heating at 60,98 and $121{ }^{\circ} \mathrm{C}$ for $15 \mathrm{~min}$, and were active in a broad range of $\mathrm{pH}$, from 1.5 up to 10.0.

The activity of the six peptides against the target bacteria is shown in Table 1. All six compounds were active against the tested Listeria spp., Enterococcus faecalis and Lb. sakei strains, and five of them were active also against Staphylococcus epidermidis. Some activity was also observed against Enterococcus canis, Enterococcus faecium and Enterococcus hirae, in a compound-dependent manner. Food and commensal strains, as well as Gram-negative strains were resistant to all compounds. S. epidermidis was sensitive whereas $S$. aureus was resistant. These results are in agreement with those reported for sakacin P (Carvalho et al. 2010) and most bacteriocins produced by acid lactic bacteria (Todorov et al. 2013; Barbosa et al. 2015). This is a typical profile of antimicrobial compounds produced by microbial strains for niche occupation (O'Connor et al. 2015).

The N-terminal sequences of the six antilisterial compounds, their molecular masses, protein sequences and similarity with other proteins are presented in Table 2. Noteworthy is that these compounds were detected in all repetitions of the purification experiments. All compounds were similar to $30 \mathrm{~S}$ or $50 \mathrm{~S}$ ribosomal proteins of $L b$. sakei subsp sakei $23 \mathrm{~K}$, but P6 was similar to a protein of unknown function. The observed average molecular masses were identical to the calculated average molecular masses, confirming the identification of the compounds.

The concentration of each compound, including sakacin $\mathrm{P}$ and peptides P1 and P1 described previously, was achieved by the fractionation of the acid extract of the culture of $L b$. sakei $2 \mathrm{a}$ and the purification steps varied between 1.00 and $16.05 \mu \mathrm{g} \cdot \mathrm{L}^{-1}$ (Table 3 ). The activity of each compound against L. monocytogenes Scott A is shown in Fig. 1, where 


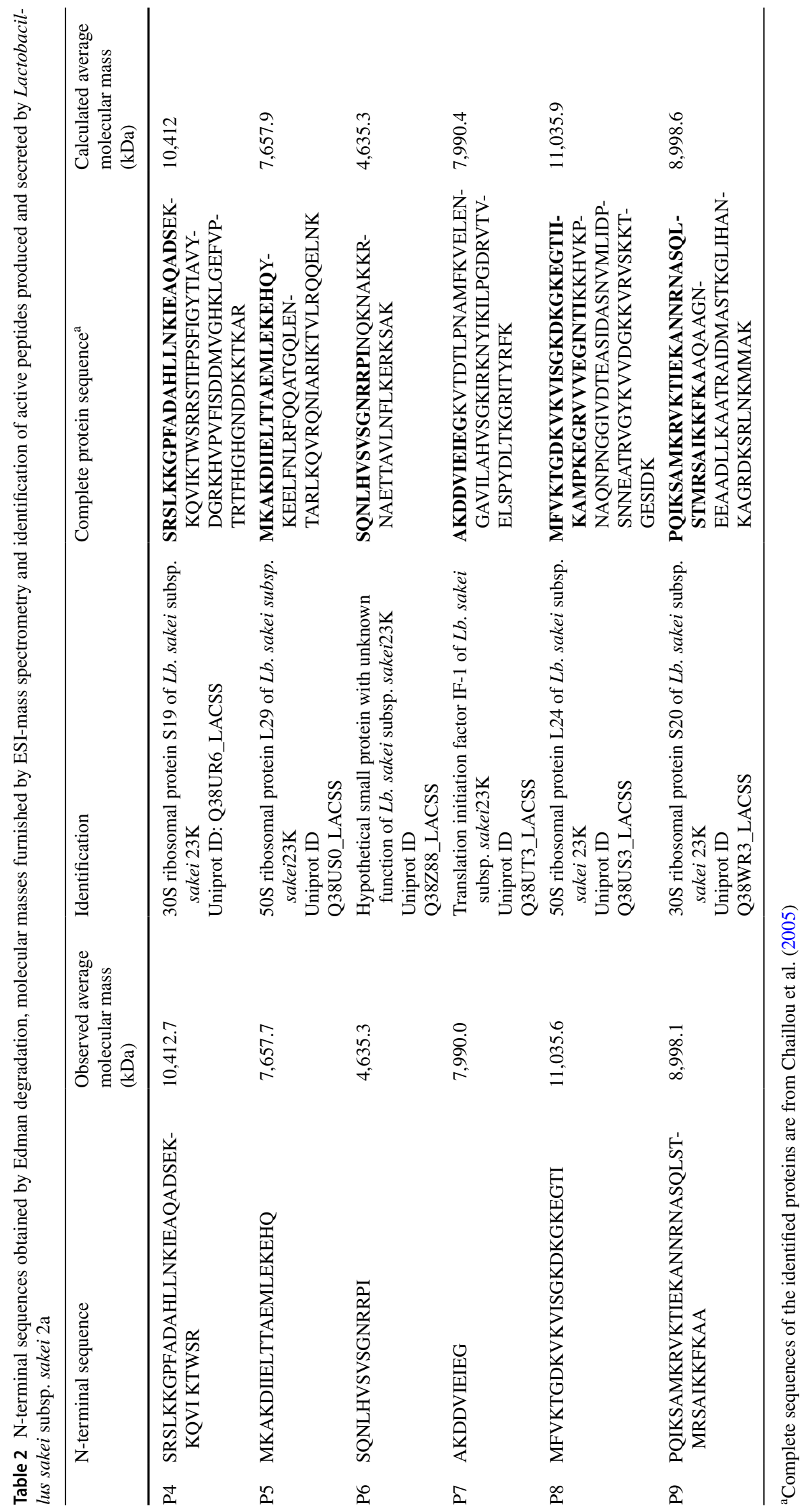


Table 3 Concentration $\left(\mu \mathrm{g} \cdot \mathrm{L}^{-1}\right)$ of the antimicrobial compounds obtained by cation-exchange fractionation of the acid extract of Lactobacillus sakei subsp. sakei $2 \mathrm{a}$

\begin{tabular}{lc}
\hline $\begin{array}{l}\text { Antimicrobial } \\
\text { compound }\end{array}$ & $\begin{array}{l}\text { Concentra- } \\
\text { tion }\left(\mu \mathrm{g} \cdot \mathrm{L}^{-1}\right)\end{array}$ \\
\hline $\mathrm{P}^{\mathrm{a}}$ & 7.65 \\
$\mathrm{P}^{\mathrm{a}}$ & 16.05 \\
$\mathrm{P}^{\mathrm{a}}$ & 15.62 \\
$\mathrm{P} 4$ & 1.90 \\
$\mathrm{P} 5$ & 2.90 \\
$\mathrm{P} 6$ & 3.40 \\
$\mathrm{P} 7$ & 1.00 \\
$\mathrm{P} 8$ & 5.48 \\
$\mathrm{P} 9$ & 5.51 \\
\hline
\end{tabular}

Separation was performed in a $\mathrm{C}_{18}$-column $(250 \times 4.6 \mathrm{~mm}$, $5 \mu \mathrm{m}, 100 \AA$ ) at room temperature. Mobile phases A and B were $0.1 \%$ aqueous trifluoroacetic acid (TFA) and $80 \%$ aqueous acetonitrile containing $0.1 \%$ TFA, respectively; flow rate was $1.0 \mathrm{~mL} \cdot \mathrm{min}^{-1}$ and detection was conducted at $280 \mathrm{~nm}$

${ }^{\mathrm{a}}$ Described in Carvalho et al. 2010

a dose-dependent activity can be seen for all, except P5. The activity of P6 and P9 was similar to nisin, for the same concentration.

The compounds P4-P9 presented similar mode of action: they decreased the membrane potential $(\Delta \Psi)$ and increased the efflux of ATP of L. monocytogenes (Figs. 2, 3, 4), though with varied intensity. However, they did not cause disruption of the $\mathrm{pH}$ gradient $(\Delta \mathrm{pH})$, as occurred with sakacin $\mathrm{P}$ (data not shown). A decrease in $\Delta \Psi$ of about $90-140$ a.u. was observed when the concentration was $1000 \mathrm{nmol} \cdot \mathrm{L}^{-1}$, which is smaller decrease than that reported for sakacin $\mathrm{P}$ (Carvalho et al. 2010).

The decrease of membrane potential $(\Delta \Psi)$ accompanied by increase of ATP efflux observed in the present study is due to the well-known mechanism by which class II bacteriocins inhibit target cells (Snyder and Worobo 2014). Modification of $\Delta \Psi$ is commonly observed for typical class IIa bacteriocins, as demonstrated for enterocin P (Herranz et al. 2001a, b), piscicocin CS526 (Suzuki et al. 2005) and sakacin P (Carvalho et al. 2010). The decrease of membrane potential $(\Delta \Psi)$ was the same for all antilisterial compounds together or when the EAF was used (unpublished data). The same occurred with the purified acid extract $\left(1600 \mathrm{AU} \cdot \mathrm{mL}^{-1}\right)$.

Results of this study suggest that some antimicrobial compounds produced by $L b$. sakei 2 a are moonlight proteins, i.e., besides their predominant function, such as ribosomal or DNA-binding, they can also have an antibacterial activity. Since these proteins are highly cationic, they can bind to nucleic acids and anionic constituents of the surface of Gram-positive bacteria and can be transported through their cell wall and membranes (Drider et al. 2006). Although unable to promote extensive membrane disruption, these proteins can affect some membrane processes such as ATP transport and maintenance of the electrochemical gradient (Chen and Montville 1995). It is important to point out that ribosomal- and nucleic acid-binding proteins may cooperate with sakacin $\mathrm{P}$ by presenting the same mechanism of action such as disruption of membrane potential and increase of ATP.

Production of multiple antimicrobial compounds by different species of lactic acid bacteria seems to be quite common (Ustyugova et al. 2012; Sawa et al. 2013; Gaaloul et al. 2014; Masuda et al. 2015; Mirkovic et al. 2016). In the study of Sawa et al. (2013), the authors observed that $L b$.
Fig. 1 In vitro antilisterial activity $\left(\mathrm{AU} \cdot \mathrm{mL}^{-1}\right)$ of the antimicrobial compounds produced by Lactobacillus sakei subsp. sakei $2 \mathrm{a}$ and nisin. (Dark square) $1000 \mathrm{nmol} \cdot \mathrm{L}^{-1}$, (dark gray square) $100 \mathrm{nmol} \cdot \mathrm{L}^{-1}$, (light gray square) $10 \mathrm{nmol} \cdot \mathrm{L}^{-1}$

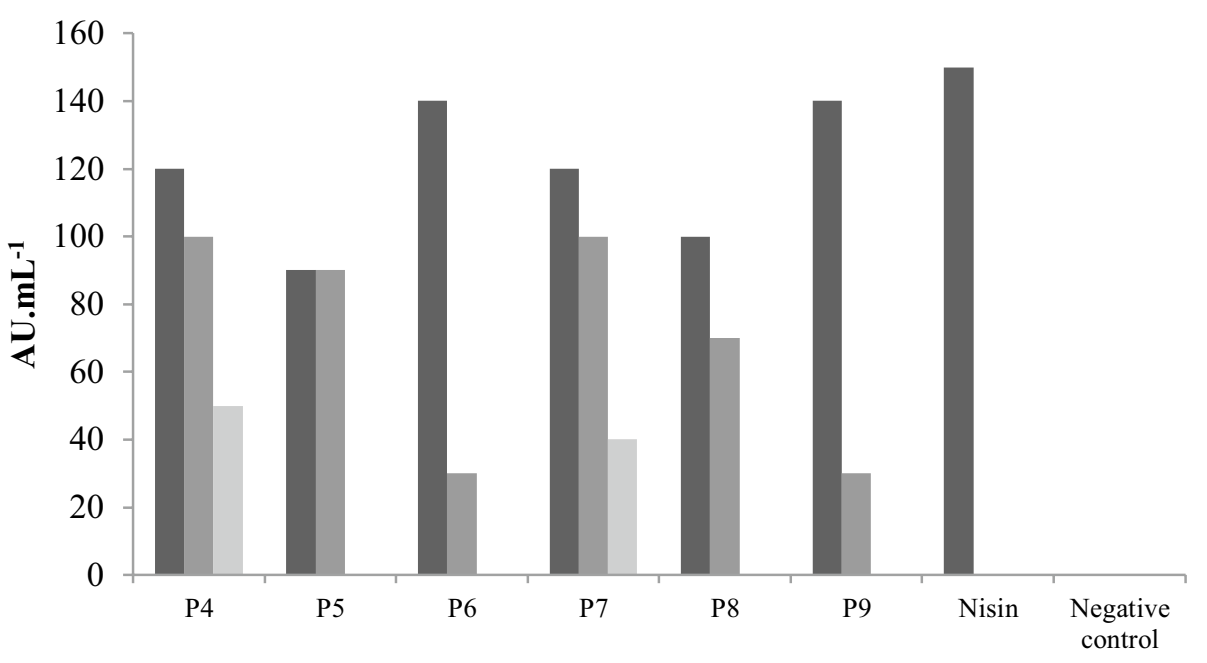

antimicrobial compound 

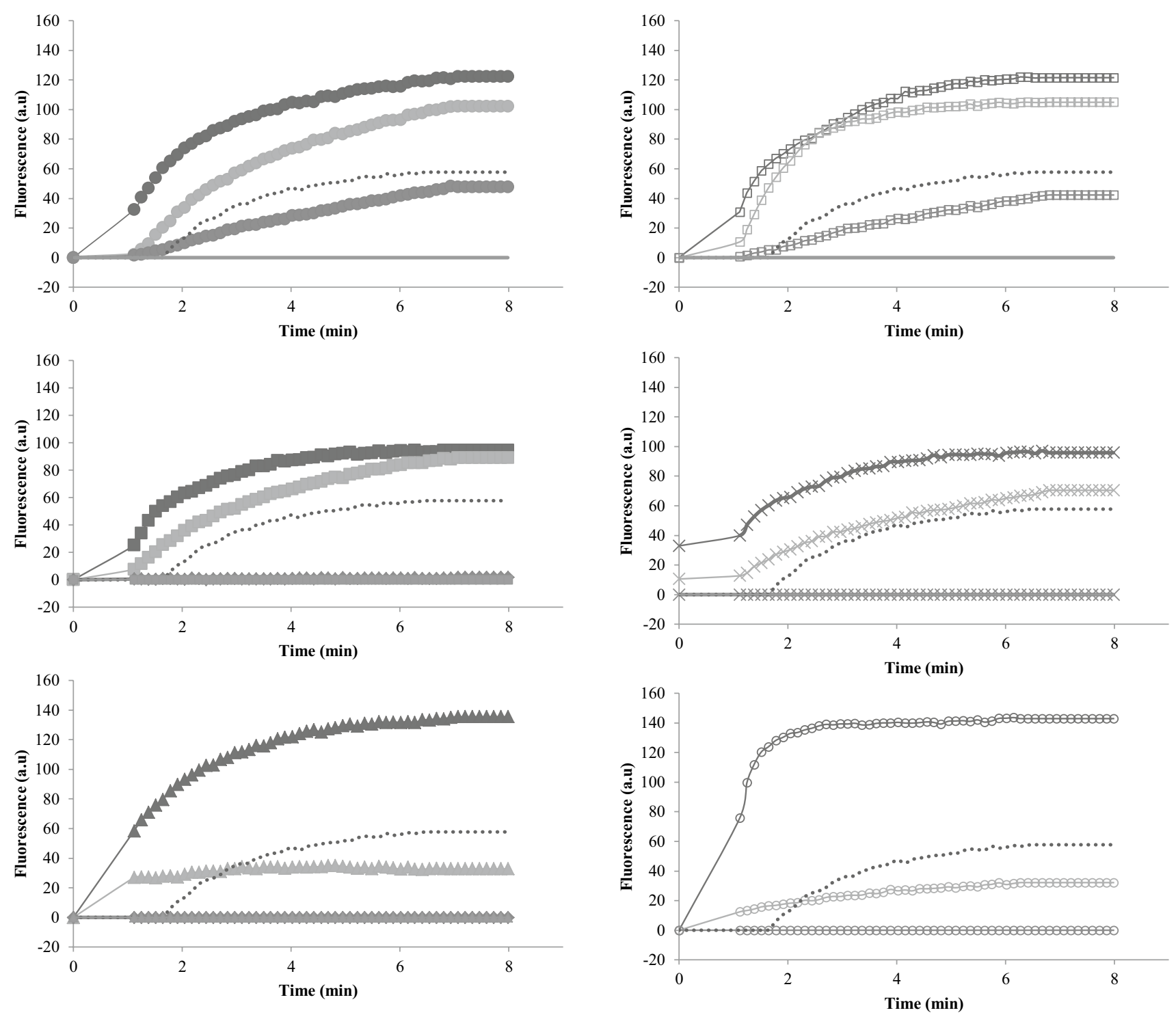

Fig. 2 Effect of compounds P4, P5 and P6 produced by Lactobacillus sakei subsp. sakei $2 \mathrm{a}$ on the membrane potential $(\Delta \Psi)$ of Listeria monocytogenes Scott A cells. Fluorescence levels before the addition of the compounds were arbitrarily set to zero, and the increase in fluorescence upon the addition of compounds was expressed in arbitrary units (a.u). Antimicrobial compounds and concentrations were: (black dot dash dot line) $\mathrm{P} 4,1000 \mathrm{nmol} \cdot \mathrm{L}^{-1}$, (light gray dot dash dot line) $\mathrm{P} 4,100 \mathrm{nmol} \cdot \mathrm{L}^{-1}$, (dark gray dot dash dot line) $\mathrm{P} 4,10 \mathrm{nmol} \cdot \mathrm{L}^{-1}$, (black dash square dash line) $\mathrm{P} 5,1000 \mathrm{nmol} \cdot \mathrm{L}^{-1}$, (light gray dash square dash line) P5, $100 \mathrm{nmol} \cdot \mathrm{L}^{-1}$, (dark gray dash square dash line) $\mathrm{P} 5,10 \mathrm{nmol} \cdot \mathrm{L}^{-1}$, (black dash triangle dash line) $\mathrm{P} 6,1000 \mathrm{nmol} \cdot \mathrm{L}^{-1}$, (light gray dash triangle dash line) P6, $100 \mathrm{nmol} \cdot \mathrm{L}^{-1}$, (dark gray dash triangle dash line) P6, $10 \mathrm{nmol} \cdot \mathrm{L}^{-1}$, (thick dash) negative control, (dark gray square dot square) nisin, $1000 \mathrm{nmol} \cdot \mathrm{L}^{-1}$

sakei D98 isolated from rice malt (Shubo) produced sakacin with a pediocin box-like sequence, and also two class IId bacteriocins (sakacins D98a and D98c). These bacteriocins presented different antimicrobial mechanisms, amino acid

Fig. 3 Effect of the compounds P7, P8 and P9 produced by Lactobacillus sakei subsp. sakei $2 \mathrm{a}$ on the membrane potential $(\Delta \Psi)$ of Listeria monocytogenes Scott A cells. Fluorescence levels before the addition of the compounds were arbitrarily designated zero, and the increase in fluorescence upon the addition of proteins was expressed in arbitrary units (a.u..). Antimicrobial compounds and concentrations were: (black dash square dash line) P7, $1000 \mathrm{nmol} \cdot \mathrm{L}^{-1}$, (light gray dash square dash line) $\mathrm{P} 7,100 \mathrm{nmol} \cdot \mathrm{L}^{-1}$, (dark gray dash square dash line) P7, $10 \mathrm{nmol} \cdot \mathrm{L}^{-1}$, (black dash times dash line) P8, $1000 \mathrm{nmol} \cdot \mathrm{L}^{-1}$, (light gray dash times dash line) $\mathrm{P} 8,100 \mathrm{nmol} \cdot \mathrm{L}^{-1}$, (dark gray dash times dash line) P8, $10 \mathrm{nmol} \cdot \mathrm{L}^{-1}$, (black dash circle dash line) P9, $1000 \mathrm{nmol} \cdot \mathrm{L}^{-1}$, (light gray dash circle dash line) $\mathrm{P} 9,100 \mathrm{nmol} \cdot \mathrm{L}^{-1}$, (dark gray dash circle dash line) $\mathrm{P} 9,10 \mathrm{nmol} \cdot \mathrm{L}^{-1}$, (dark dash) negative control, (dark gray square dot square), nisin, $1000 \mathrm{nmol} \cdot \mathrm{L}^{-1}$

sequences and disulfite bridges in their molecules, which are characteristics also observed for the mat isolate $L b$ sakei 2a. Lb. sakei $\mathrm{D} 98$ is part of the starter culture used in the production of Shubo, so Sawa et al. (2013) considered that 
Fig. 4 Effect of the antimicrobial compounds produced by Lactobacillus sakei subsp. sakei $2 \mathrm{a}$ on the ATP efflux from Listeria monocytogenes Scott A cells. Bioluminescence levels before the addition of the compounds were arbitrarily designated zero, and the increase in bioluminescence upon the addition of the compounds was expressed in ATP concentration (nmol. $\mathrm{mg}^{-1}$ ). The compounds and nisin concentrations were: (black square) $1.0 \mu \mathrm{mol} \cdot \mathrm{L}^{-1}$, (dark gray square)

$0.5 \mu \mathrm{mol} \cdot \mathrm{L}^{-1}$, (light gray square) $0.25 \mu \mathrm{mol} \cdot \mathrm{L}^{-1}$, (lighter gray square) $0.1 \mu \mathrm{mol} \cdot \mathrm{L}^{-1}$

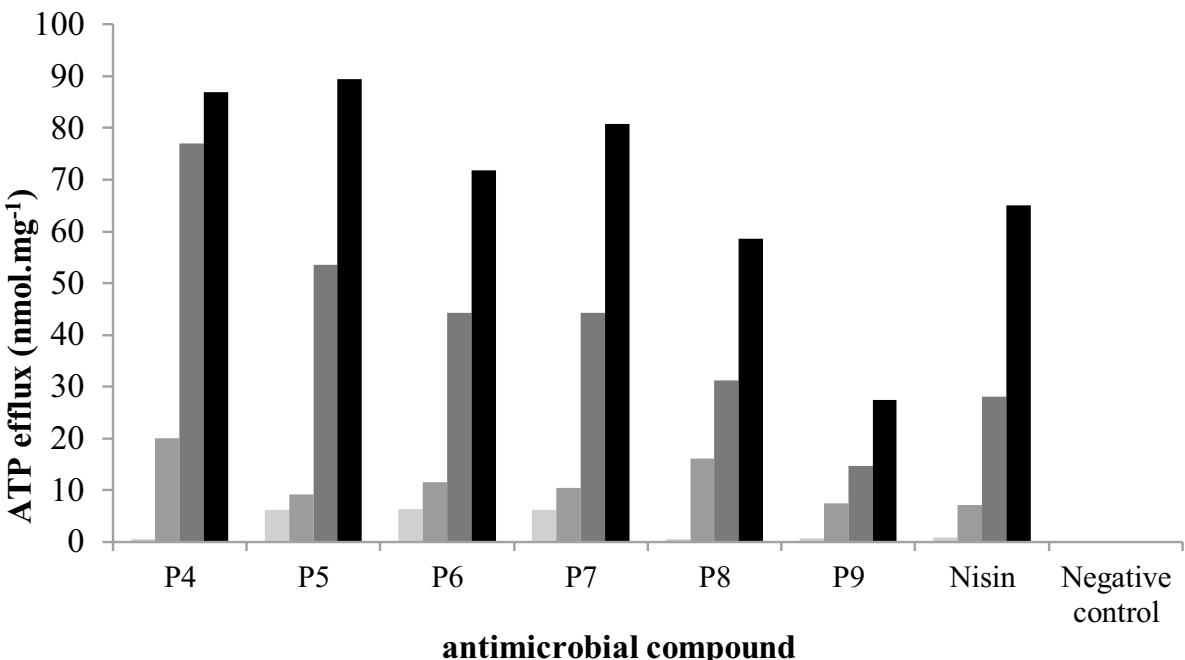

antimicrobial compound it may play an important role in controlling growth of other microorganisms by the production of bacteriocins in addition to organic acids. However, the multiple bacteriocins produced by $L b$. sakei D98 did not present a synergistic effect, as also observed for the strain tested in the present study (Lb. sakei 2a).

Other authors have also studied peptides with antimicrobial activity which are not recognized as classical bacteriocins. Miao et al. (2016) evaluated a novel peptide (F1) produced by Lactobacillus paracasei subsp. tolerans FX-6, isolated from Tibetan kefir. F1 showed a wide antimicrobial spectrum against bacteria and fungi, and stability to protease, $\mathrm{pH}$ and heat treatments. This peptide contained 18 amino acids and its antimicrobial mechanism against Escherichia coli was related to the membrane permeability and the leakage of the cytoplasmic $\beta$-galactosidase and potassium ions. The results showed that the antimicrobial peptide F1 could penetrate and accumulate into cell causing disruption of cell membrane functions, in addition to a DNA-binding ability. Hence, F1 depicted multiple cell targets in the killing of E. coli.

Xiao and Niu (2015) verified the production of the antilisterial peptides released by enzymatic hydrolysis from grass carp proteins and then evaluated their antilisterial activity against L. monocytogenes inoculated in surimi noodle for storage at 4 and $25^{\circ} \mathrm{C}$ up to 20 days. The results indicated that antilisterial peptides produced by enzymatic hydrolysis from grass carp proteins can inhibit the growth of L. monocytogenes in surimi noodle, which was useful as natural food preservatives of meat products.

When tested in the meat gravy model simulating a processed food, both the Lb. sakei 2 a culture and the enriched active fraction (EAF) of the culture inhibited the growth of L. monocytogenes (Fig. 5), regardless the final concentration of the acid extract in the gravy $\left(0.1\right.$ or $\left.0.2 \% \mathrm{w} \cdot \mathrm{v}^{-1}\right)$. In the control experiment, the count of L. monocytogenes Scott
A in the gravy stored at $4{ }^{\circ} \mathrm{C}$ was $5.0 \log \mathrm{CFU} \cdot \mathrm{mL}^{-1}$ after 5 days and remained the same until the 10th day. In the gravy containing the bacteriocinogenic strain or the acid extract, the growth of L. monocytogenes was inhibited to an extent that the population of the pathogen in the product stored at $4{ }^{\circ} \mathrm{C}$ for 5 days was 0.6 to $1 \log$ lower than the initial population $\left(10^{3} \mathrm{CFU} \cdot \mathrm{mL}^{-1}\right)$. These differences were statistically significant $(p<0.05)$, supporting the potential application of Lb. sakei $2 \mathrm{a}$ or the $\mathrm{EAF}$ in foods for biopreservation.

The EAF from Lb. sakei 2 a presented similar and even better inhibitory activity against $L$. monocytogenes than the culture in a simulated meat product during storage under refrigeration up to 10 days. This enhanced activity of the extract when compared to the culture may be due to the lag time needed for the bacteriocinogenic strain to adapt to the meat gravy model before starting production of the antimicrobial compounds. Furthermore, the in situ production of these compounds may be hampered by components in the food matrix and unfavorable environmental conditions for growth, such as $\mathrm{pH}$ and salt or sugar content (Urso et al. 2006).

Castellano et al. (2016) evaluated the antilisterial peptides from Spanish dry-cured hams produced during the ripening from the hydrolysis of the muscle proteins by muscle peptidases. Ten peptides showed antilisterial activity and these results proved novel natural strategies and alternative to chemical compounds for potential antimicrobial action against L. monocytogenes.

The combination of one or more antilisterial compounds either produced in situ or added to the product is effective to reduce the survival or regrowth of Listeria populations in model systems. Normally, the resistance of the strains is observed in foods because changes in the fatty acid composition of the membrane and alterations in the cell envelope (Abee 1995). Therefore, a useful alternative would be the combined use of one or more antilisterial compounds to 


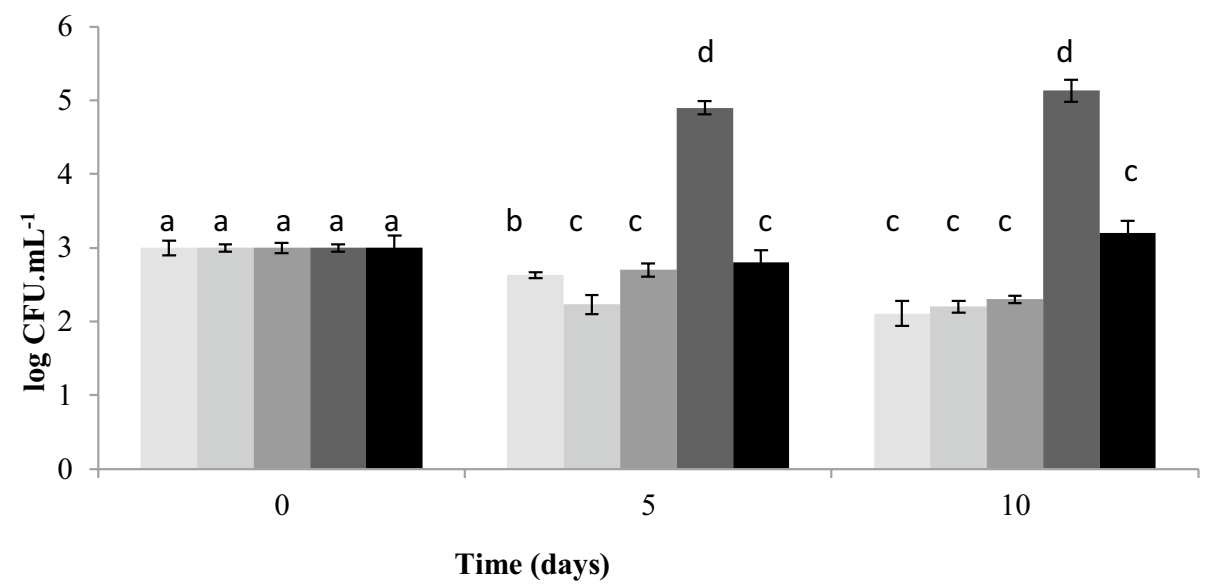

Fig. 5 Counts of Listeria monocytogenes $\left(\log \mathrm{CFU} \cdot \mathrm{mL}^{-1}\right)$ in the meat gravy model containing (lighter gray square) L. monocytogenes + enriched active fraction (EAF) $0.1 \%\left(\mathrm{w} \cdot \mathrm{v}^{-1}\right)$; (light gray square) L. monocytogenes + enriched active fraction (EAF) $0.2 \%$

ensure the food safety and avoid the emergence of resistant bacteria strains.

In conclusion, results obtained from this study indicate that $L b$. sakei 2 a is capable to produce several antimicrobial compounds and these compounds or a culture of this strain have a potential for application in processed food by the inhibition of growth of L. monocytogenes and other closely related bacteria thereby increasing the shelf life of the products. Further scale-up studies, where enough amount of each antilisterial peptide will be obtained and tested in food models, will clarify the role of each peptide in the inhibition of L. monocytogenes, and a possible synergistic effect could be evaluated and explored as strategy for effective biopreservation of foods.

Acknowledgements The study was supported by FAPESP (Processes 2004/08041-9, 2005/60619-8 and 2013/07914-8) and FAPEMIG (EDT $24,000)$ Grants.

\section{Compliance with ethical standards}

Conflict of interest No conflict of interest declared.

\section{References}

Abee T (1995) Pore-forming bacteriocins of gram-positive bacteria and self-protection mechanisms of producer organisms. FEMS Microbiol Lett 129:1-10

Alves VF, Lavrador MAS, De Martinis ECPP. (2003) Bacteriocin exposure and food ingredients influence on growth and virulence of Listeria monocytogenes in a model meat gravy system. J Food Saf 23:201-217

Barbosa MS, Todorov SD, Ivanova I, Chobert JM, Haertl T, Franco BDGM. (2015) Improving safety of salami by application of $\left(\mathrm{w} \cdot \mathrm{v}^{-1}\right)$; (dark gray square) L. monocytogenes + Lb. sakei subsp sakei 2a (darker gray square) L. monocytogenes, (black square) L. monocytogenes + nisin $0.1 \%\left(\mathrm{w} \cdot \mathrm{v}^{-1}\right){ }^{\mathrm{a}, \mathrm{b}, \mathrm{c}, \mathrm{d}}$ Different letters indicate statistically significant differences $(p<0.05)$

bacteriocins produced by an autochthonous Lactobacillus curvatus isolate. Food Microbiol 46:254-262

Bradford MM (1976) Rapid and sensitive method for quantification of microgram quantities of proteins utilizing principle of protein-dye binding. Anal Biochem 72:248-254

Buchanan RL, Gorris L, Hayman MM, Jackson TC, Whiting RC (2017) A review of Listeria monocytogenes: an update on outbreaks, virulence, dose-response, ecology, and risk assessments. Food Control 75:1-13

Carvalho KG, Bambirra FHS, Kruger MF, Barbosa MS, Oliveira JS, Santos AMC, Nicoli JR, Bemquerer MP, Miranda A, Salvucci EJ, Sesma FJM, Franco BDGM. (2010) Antimicrobial compounds produced by Lactobacillus sakei subsp. sakei $2 \mathrm{a}$, a bacteriocinogenic strain isolated from a Brazilian meat product. J Ind Microbiol Biotechnol 37:381-390

Castellano P, Mora 1, Escudero E, Vignolo G, Aznar R, Toldra F (2016) Antilisterial peptides from Spanish dry-cured hams: purification and identification. Food Microbiol 59:133-141

Chaillou S, Champomier-Verges M, Cornet M, Crutz Lecoq AM, Dudez AM, Martin V, Beaufils S, Darbon-Rongere E, Bossy R, Loux V, Zagorec M (2005) The genome sequence of the meatborne lactic acid bacterium Lactobacillus sakei $23 \mathrm{~K}$. Nat Biotechnol 23:1527-1533

Chen Y, Montville TJ (1995) Efflux of ions and ATP depletion induced by pediocin PA-1 are concomitant with cell death in Listeria monocytogenes Scott A. J Appl Bacteriol 79:684-690

De Martinis ECP, Franco BDGM. (1998) Inhibition of Listeria monocytogenes in a pork product by a Lactobacillus sake strain. Int $\mathrm{J}$ Food Microbiol 42:119-126

Drider D, Fimland G, Héchard Y, McMullen LM, Prévost H (2006) The continuing story of class IIa bacteriocins. Microbiol Mol Biol Rev 70:564-582

Farias LM, Totola AH, Miranda CMS, Carvalho MAR, Damasceno CAV (1994) Extraction, partial purification and characterization of a bacteriocin (fragilicin) produced by a strain of Bacteroides fragilis isolated from Callithrix penicillata. Res Microbiol 145:9-16

Gaaloul N, Braiek OB, Hani K, Volski A, Chikindas ML, Ghrairi T (2014) Isolation and characterization of large spectrum and multiple bacteriocin-producing Enterococcus faecium strain from raw bovine milk. J Appl Microbiol 118:343-355 
Guihard G, Benedettig SH, Besnard M, Letelliern L (1993) Phosphate efflux through the channels formed by colicins and phage T5 in Escherichia coli cells is responsible for the fall in cytoplasmic ATP. J Biol Chem 268:17775-17780

Herranz C, Cintas LM, Hernandez PE, Moll GN, Driessen AJ (2001a) Enterocin P causes potassium ion efflux from Enterococcus faecium T136 cells. Antimicrob Agents Chemother 45:901-904

Herranz C, Chen Y, Chung HJ, Cintas LM, Hernandez PE, Montville TJ, Chikindas ML (2001b) Enterocin P selectively dissipates the membrane potential of Enterococcus faecium T136. Appl Environ Microbiol 67:1689-1692

Masuda Y, Perez RH, Zendo T, Sonomoto K (2015) Nutrition-adaptative control of multiple bacteriocin production by Weissella hellenica QU 13. J Appl Microbiol 120:70-79

Miao J, Liu G, Ke C, Fan W, Li C, Chen Y, Dixon W, Song M, Cao Y, Xiao H (2016) Inhibitory effects of a novel antimicrobial peptide from kefir against Escherichia coli. Food Control 65:63-72

Mirkovic N, Polovic N, Vukotic G, Jovcic B, Miljkovic M, Rdaulovic Z, Diep DB, Kojic M (2016) Lactococcus lactis LMG2081 produces two bacteriocins, a nonlantibiotic and a novel lantibiotic. Appl Environ Microbiol 82:2555-2562

O'Connor PM, Ross RP, Hill C, Cotter PD (2015) Antimicrobial antagonists against food pathogens: a bacteriocin perspective. Curr Opin Food Sci 2:51-57

Rosa CM, Franco BDGM., Montville TJ, Chikindas M (2002) Purification and mechanistic action of a bacteriocin produced by a Brazilian sausage isolate, Lactobacillus sakei 2a. J Food Saf 22:39-54

Sawa N, Koga S, Okamura K, Ishibashi N, Zendo T, Sonomoto K (2013) Identification and characterization of novel multiple bacteriocins produced by Lactobacillus sakei D98. J Appl Microbiol 115:61-69

Snyder AB, Worobo RW (2014) Chemical and genetic characterization of bacteriocins: antimicrobial peptides for food safety. J Sci Food Agric 94:28-44

Suzuki M, Yamamoto T, Kawai Y, Inoue N, Yamazaki K (2005) Mode of action of piscicocin CS526 produced by Carnobacterium piscicola CS526. J Appl Microbiol 98:1146-1151

Todorov SD, Vaz-Velho M, Franco BDGM., Holzapfel WH (2013) Partial characterization of bacteriocins produced by three strains of Lactobacillus sakei, isolated from salpicao, a fermented meat product from North-West of Portugal. Food Control 30:111-121

Urso R, Rantsiou K, Cantoni C, Comi G, Cocolin L (2006) Technological characterization of a bacteriocin-producing Lactobacillus sakei and its use in fermented sausages production. Int J Food Microbiol 110:232-239

Ustyugova EA, Timofeeva AV, Stoyanova LG, Netrusov AI, Katrukha GS (2012) Characteristics and identification of bacteriocins produced by Lactococcus lactis subsp lactis 194-K. Appl Biochem Microbiol 48:557-563

Xiao J, Niu L (2015) Antilisterial peptides released by enzymatic hydrolysis from grass carp proteins and activity on controlling Listeria monocytogenes inoculated in surimi noodle. J Food Sci 80:M2564-M2569

Yang R, Johnson MC, Ray B (1992) Novel method to extract large amounts of bacteriocins from lactic acid bacteria. Appl Environ Microbiol 58:3355-3359 